\title{
Analysis of Income Tax Liability Implementation at ABC Corporation
}

\author{
Punamawati Helen Widjaja \\ Accounting Study Program, Faculty of Economics and Business \\ Tarumanagara University, Jakarta
}

\begin{abstract}
In Indonesia, tax is the main source of state revenue that is used maximally for the general public's welfare. Tax collection is one of Indonesia's important things, where most of the revenue comes from income tax. This study aims to analyze the corporate income tax liability at ABC Coporation, which is under Law Number 36, the Year 2008. The research method uses a descriptive analysis method. The calculation of tax liabilities in this study is divided into several income tax articles, and fiscal corrections are made on the company's income statement. The results showed that ABC Corporation calculates, payment and reports Corporate Income Tax under Law Number 36 of 2008.
\end{abstract}

Keywords: Calculation, Payment, Reporting, Corporate Income Tax, Law Number 36 Year 2008

DOI: $10.7176 /$ RJFA/12-10-08

Publication date:May $31^{\text {st }} 2021$

\section{INTRODUCTION}

Taxation in Indonesia has developed since the pre-colonial era, and tax collection is important for the Indonesian state. Taxes mentioned in Article 23A of the 1945 Constitution are compulsory levies for state needs as regulated in law. Taxes are the largest and most important source of state income in Indonesia. With taxes, the state can carry out national development to improve people's welfare. National development that the state can carry out can be to improve educational facilities, health facilities, public facilities, and development in areas that are still underdeveloped so that the welfare of the people in each region is equal. To support national development, the government must increase efforts to understand the importance of taxes so that taxpayers have the awareness to pay and report taxes according to the actual conditions.

According to Law Number 28 of 2007 Article 1 paragraph (2), people who have tax rights and obligations are taxpayers divided into individuals or entities, comprising tax payer and withholding agent having taxations rights and obligations pursuant to the provisions of the tax laws.

A corporate Taxpayer is a company in the form of a domestic company established or domiciled in Indonesia. Companies that are included as taxpayers are subject to Corporate Income Tax (CIT), which is based on certain income that the company receives for one year. Corporate taxpayers must have bookeeping and compile financial reports in the form of a balance sheet and profit and loss statement and calculate income tax at the end of each tax year. Income tax calculations are made using the financial statements reported by the company following applicable tax regulations. Since 1983, tax regulations have changed by entrusting taxpayers to calculate, report, and payment their tax obligations (Self Assessment System). This surrender of trust requires taxpayers to understand taxation provisions well because the law gives authority to the Directorate General of Taxes to enforce the law by supervising taxpayers. If the taxpayer makes a mistake in calculating and paying taxes, he will face administrative sanctions and lead to criminal sanctions.

In applying the Self Assessment System in the current era, there is the possibility of errors in tax calculations and payments due to the lack of understanding of the taxpayers. So that in carrying out the activities of a business entity, Corporate Taxpayers must know several types of Income Tax that can be imposed on the company. According to Law Number 36, the Year 2008, there are several types of Income Tax, namely Income Tax Article 21, Article 22, Article 23, Article 24, Article 25, Article 26, Article 29, and Article 4 (2). In these articles, it is explained that the tax objects are the responsibility of taxation with various imposition rates. According to taxation (fiscal) rules and corporate (commercial) accounting rules, the recognition of income and expenses can be different. Therefore, there are often differences in the calculation of income tax between companies and tax authorities so that fiscal adjustments are needed to determine the company's tax following applicable tax regulations.

This research is expected to be a reference for other corporate taxpayers in implementing the Self Assessment System so that there are no miscalculations and tax payments caused by taxpayers' ignorance of taxation laws and regulations. Also, because differences in revenue and expense recognition between companies and tax authorities can affect the calculation and payment of Corporate Income Tax, companies need to make fiscal adjustments to obtain the amount of fiscal income used in calculating Corporate Income Tax. 


\section{THEORITICAL REVIEW}

\section{Taxation}

According to Law Number 28 of 2007, taxes are compulsory contributions of the people to the state-owned by private persons or entities that are compelling based on the provisions of the Law, without receiving direct remuneration and are used for state needs full welfare of the people. Another opinion expressed by Supryanto (2014) that taxes are mandatory fees or levies collected by the government from the people, namely taxpayers, to finance routine state expenditures and development costs without remuneration that can be submitted directly, but the taxes paid by the community have a direct impact towards the prosperity of society such as the construction of roads, bridges and other public places. Meanwhile, Ayza (2016) states that taxes are contributions to the state (which can be enforced) owed by those who are obliged to pay them according to the regulations without getting back performance, which can be directly appointed and whose use is to finance general expenses related to state duties to run the government. According to Andriani 2014 in Nur 2019, taxes are dues to the state (enforced) owed by those who are obliged to pay them according to the regulations without getting a return that can be directly demonstrated and whose use is to pay for general expenses related to state duties organizes by the government.

\section{Income tax}

According to Law Number 36 of 2008, Income Tax is a tax imposed on tax subjects on income earned or received in one tax year. Another definition conveyed by Official (2014) is that income tax is a tax imposed on tax subjects, namely individuals or entities, on income received and earned in the tax year. Meanwhile, a different opinion is conveyed by (Sari 2013; Lewa et al., 2018) that Income Tax Article 21 is income tax that each employer must deduct in the form of salaries, wages, honoraria, allowances, awards, and other payments, which they pay or are owed to domestic individuals.

\section{Corporate Income Tax}

According to Prisilia (2020), Corporate Income Tax is imposed on taxpayers under Law Number 36 of 2008 , namely domestic tax subjects, which are business entities that are established or domiciled in Indonesia. It is also conveyed in the research of Bagianto et al. (2018), in article 1. of the Income Tax Law Number 36 of 2008, Income Tax is a tax on the tax subject on income received or earned in a tax year. Corporate Income Tax is a tax imposed on income received or obtained by an entity referred to in the Law on General Tax Provisions No. 16 of 2009. Domestic Taxpayers, namely entities that are established or domiciled in Indonesia. 2. Overseas corporate taxpayers, namely entities that are not established or domiciled in Indonesia that carry out business or carry out activities through a permanent establishment in Indonesia, and or entities that are not established and domiciled in Indonesia that receive income from Indonesia are not from doing business through a permanent establishment in Indonesia.

\section{Fiscal Correction}

According to Suandy (2011), fiscal correction is an adjustment made by Corporate Taxpayers and Individual Taxpayers before calculating Income Tax and then compiled into a fiscal financial report. According to Rian (2014), the fiscal financial report is a financial report prepared using accounting standards or methods, but the provisions are adjusted to the applicable tax regulations. In Sondakh's (2016) research, fiscal correction is a process of adjusting commercial profit different from fiscal provisions to generate net income/profit following taxation provisions (Sari, 2012). The fiscal correction process is carried out by adjusting the fiscal records of commercial, financial statements with tax regulations (Ayu et al., 2014).

\section{Relations Between Variables}

a. Financial Reporting with Taxation

Tax is one of the obligations for taxpayers so that every activity recorded by the company in the financial statements must be following the taxation provisions in force in Indonesia. Companies must ensure that the preparation of financial statements follows the current tax regulations.

b. Financial Statements with Income Tax

This study analyzes corporate taxpayers' tax obligations by looking at the transactions recorded by companies in their financial statements. A transaction is a tax object of income tax under Law Number 36 the Year 2008.

\section{c. Financial Statements with Corporate Income Tax.}

The subjects in this study were domestic corporate taxpayers. They were founded and domiciled in Indonesia which the calculation of the tax liability is also adjusted to the provisions of the Corporate Income Tax.

\section{d. Financial Statements with Fiscal Corrections}

In calculating the amount of corporate income tax, companies need to make fiscal corrections to adjust commercially prepared financial reports with tax provisions. There are differences in recognition of revenues and expenses between the Financial Accounting Standards and tax regulations. 


\section{Research Framework}

This research was conducted in three different stages. The first stage is planning, which determines the study's title, the dependent variable, and the independent variable. In this study, the Corporate Taxpayer, namely $\mathrm{ABC}$ Corporation is the dependent variable, and the Income Tax Liability is the independent variable.

The second stage is the implementation stage; data related to research are collected. Data collection is carried out from Commercial and Fiscal Financial Reports, Positive and Negative Fiscal Corrections, 2020 Annual Tax Returns (ATR), Periodic Tax Returns for Income Tax Article 21, Income Tax Article 22, Income Tax Article 25, Income Tax Article 4 Paragraph (2), and Evidence Tax Payment. Then the data is used to analyze the tax obligations of ABC Corporation for the year ended 2020

The third stage has completed stage a conclusion is made based on the data that has been processed in the previous two stages. At this stage, recommendations are also made for ABC Corporation as input for the company's tax obligations in the following year.

\section{METHOD}

This study used a descriptive analysis research design. According to Sugiono (2016), descriptive research itself is a study that describes existing data but does not aim to draw conclusions or ideas in general. Simultaneously, descriptive analysis is research conducted by collecting data or information, facts, and evidence from the object under study, which will then be used to answer existing research problems.

The object of this research is the financial statements of ABC Corporation in 2020. The data used in this study are primary data and secondary data. Primary data is data obtained by researchers directly from the source, such as interview data. Meanwhile, secondary data is not obtained by researchers directly from the source but through intermediaries such as the 2020 Profit and Loss Statement, Annual Corporate Income Tax Return, Article 22, Article 25, Article 4 Paragraph (2) Periodic Income Tax Returns. , Proof of Withholding Income Tax Article 21, Proof of Deposit in the form of Proof of State Revenue, and Proof of Report in the form of E-Filing. The location of this research is ABC Corporation, which is located in Jakarta. ABC Corporation is an importer company that has Import Identification Number and also has a Bonded Warehouse in its business activities.

Researchers' data collection techniques in conducting this research consisted of two ways, namely (1) Field Research, which is a data collection technique conducted by researchers by going directly to the object of research to obtain more detailed and clear data. Field research is divided into two ways: observation (observation), which is done by observing the object being examined directly. The aim is to obtain factual information and data about any tax obligations imposed on $\mathrm{ABC}$ Corporation. Then then find out the calculations, deposits, and reporting carried out by $\mathrm{ABC}$ Corporation, and interviews conducted by researchers conducting interviews or direct questions and answers to certain parties. The aim is to obtain relevant information with this research, namely the tax obligations at ABC Corporation, (2) Library research is a data collection technique theoretically carried out by researchers by obtaining information from several books, documents, and writings related to research.

The data processing technique used by researchers in conducting this research consists of several stages:

1) Re-examine the data that has been obtained and collected by researchers relating to the completeness, accuracy, and suitability of ABC Corporation.

2) Processing data from the first stage results by arranging data into groups or recording data in table form to facilitate evaluation.

3) Provide information in the form of additional explanation on certain data as a researcher notes in understanding the data that is being processed.

4) Perform recalculation as a way for researchers to recheck the calculations that the company has done.

5) Perform re-examination on fiscal corrections made by ABC Corporation, to determine whether the correction is under the applicable taxation provisions, and the researcher is to find out the legal basis of the fiscal correction.

6) Comparing the results of calculations that have been recorded by the company with the results of calculations made by researchers based on applicable tax rates and provisions, for example, Law Number 36 the Year 2008 and other tax regulations.

7) Checking the suitability of the calculation, payment, and reporting of each Income Tax obligation imposed on ABC Corporation. For example, with applicable tax provisions, Law Number 36 the Year 2008, and other tax regulations.

8) Provide conclusions on the results of the analysis carried out in this study. 


\section{RESULT AND DISCUSSION}

Table 1. Withholding Income Tax Article 21 ABC Corporation of 2020 (in Rupiah)

\begin{tabular}{|c|c|c|c|c|}
\hline No. & Tax period & One Year's Gross Income & Withholding Tax Income 21 & Tax Payment Date \\
\hline 1. & January & $47.566 .667,00$ & $3.666 .667,00$ & $07 / 02 / 2020$ \\
\hline 2. & February & $47.566 .667,00$ & $3.666 .667,00$ & $09 / 03 / 2020$ \\
\hline 3. & March & $47.566 .667,00$ & $3.666 .667,00$ & $08 / 04 / 2020$ \\
\hline 4. & April & $47.566 .667,00$ & $3.666 .667,00$ & $08 / 05 / 2020$ \\
\hline 5. & May & $98.869 .375,00$ & $11.069 .375,00$ & $10 / 06 / 2020$ \\
\hline 6. & June & $47.747 .208,00$ & $3.847 .208,00$ & 09/07/2020 \\
\hline 7. & July & $26.053 .750,00$ & $853.750,00$ & $10 / 08 / 2020$ \\
\hline 8. & August & $26.053 .750,00$ & $853.750,00$ & $11 / 09 / 2020$ \\
\hline 9. & September & $26.053 .750,00$ & $853.750,00$ & $09 / 10 / 2020$ \\
\hline 10. & October & $26.053 .750,00$ & $853.750,00$ & $10 / 11 / 2020$ \\
\hline 11. & November & $26.053 .750,00$ & $853.750,00$ & $08 / 12 / 2020$ \\
\hline 12. & December & $26.053 .750,00$ & $853.750,00$ & $08 / 01 / 2021$ \\
\hline
\end{tabular}

Table 2. Recapitulation of Income Tax Article 22 ABC Corporation of 2020 (in Rupiah)

\begin{tabular}{|c|c|c|c|c|}
\hline Tax Period & $\begin{array}{l}\text { Tax Imposition Base } \\
\text { Amount }\end{array}$ & Rates & Income Tax 22 Withheld & $\begin{array}{l}\text { Proof of withholding } \\
\text { Date }\end{array}$ \\
\hline \multirow[t]{6}{*}{ January } & $175.230 .047,26$ & $2.5 \%$ & 4.381 .000 & $06 / 01 / 2020$ \\
\hline & $350.967 .919,80$ & $2.5 \%$ & 8.775 .000 & $30 / 01 / 2020$ \\
\hline & $353.410 .633,98$ & $2.5 \%$ & 8.836 .000 & $09 / 01 / 2020$ \\
\hline & $141.070 .304,34$ & $2.5 \%$ & 3.527 .000 & $30 / 01 / 2020$ \\
\hline & $141.935 .330,92$ & $2.5 \%$ & 3.549 .000 & $16 / 01 / 2020$ \\
\hline & 1.162.614.236,30 & & 29.068 .000 & \\
\hline \multirow[t]{3}{*}{ February } & $141.218 .794,28$ & $2.5 \%$ & 3.538 .000 & $14 / 02 / 2020$ \\
\hline & $141.898 .688,35$ & $2.5 \%$ & 3.548 .000 & $14 / 02 / 2020$ \\
\hline & $283.117 .482,63$ & & 7.086 .000 & \\
\hline \multirow[t]{3}{*}{ March } & $280.613 .747,90$ & $2.5 \%$ & 7.016 .000 & $10 / 03 / 2020$ \\
\hline & $191.329 .761,00$ & $2.5 \%$ & 4.784 .000 & $26 / 03 / 2020$ \\
\hline & 471.943.508,90 & & 11.800 .000 & \\
\hline \multirow[t]{4}{*}{ April } & $144.306 .282,69$ & $2.5 \%$ & 3.608 .000 & $09 / 04 / 2020$ \\
\hline & $360.567 .105,40$ & $2.5 \%$ & 9.015 .000 & $13 / 04 / 2020$ \\
\hline & $278.942 .491,20$ & $2.5 \%$ & 6.983 .000 & $21 / 04 / 2020$ \\
\hline & 783.815.879,29 & & 19.606 .000 & \\
\hline \multirow[t]{4}{*}{ October } & $281.123 .324,70$ & $2.5 \%$ & 7.029 .000 & $08 / 10 / 2020$ \\
\hline & $280.836 .492,00$ & $2.5 \%$ & 7.021 .000 & $27 / 10 / 2020$ \\
\hline & $279.306 .198,72$ & $2.5 \%$ & 6.983 .000 & $27 / 10 / 2020$ \\
\hline & $841.266 .015,42$ & & 21.033.000 & \\
\hline November & $350.371 .841,44$ & $2.5 \%$ & 8.760 .000 & $05 / 11 / 2020$ \\
\hline Total & 3.893.128.963,98 & $2.5 \%$ & 97.353.000 & \\
\hline
\end{tabular}

Table 3. Recapitulation of Income Tax Article 25 ABC Corporation of 2020 (in Rupiah)

\begin{tabular}{|l|c|l|}
\hline Tax Period & Income Tax Art 25 & Payment Date \\
\hline January & $16.452 .809,00$ & $07 / 02 / 2020$ \\
\hline February & $16.452 .809,00$ & $09 / 03 / 2020$ \\
\hline March & $16.452 .809,00$ & $08 / 04 / 2020$ \\
\hline April & $8.623 .793,00$ & $08 / 05 / 2020$ \\
\hline May & $8.623 .793,00$ & $10 / 06 / 2020$ \\
\hline June & $8.623 .793,00$ & $09 / 07 / 2020$ \\
\hline July & $8.623 .793,00$ & $10 / 08 / 2020$ \\
\hline August & $8.623 .793,00$ & $10 / 09 / 2020$ \\
\hline September & $8.623 .793,00$ & $09 / 10 / 2020$ \\
\hline October & $8.623 .793,00$ & $10 / 11 / 2020$ \\
\hline November & $8.623 .793,00$ & $08 / 12 / 2020$ \\
\hline December & $8.623 .793,00$ & $08 / 01 / 2021$ \\
\hline Total & $126.972 .564,00$ & \\
\hline
\end{tabular}


Table 4. Recapitulation of Income Tax Article 4 paragraph 2 ABC Corporation of 2020 (in Rupiah)

\begin{tabular}{lllllrl}
\hline $\begin{array}{l}\text { Tax } \\
\text { Period }\end{array}$ & $\begin{array}{l}\text { Type } \\
\text { Transaction }\end{array}$ & $\begin{array}{l}\text { Tax Imposition Base } \\
\text { Amount }\end{array}$ & Rate & $\begin{array}{l}\text { Income } \\
\text { Article } \\
\text { Paragraph (2) } \\
\text { withheld }\end{array}$ & $\begin{array}{r}\text { Tax } \\
\text { 4 }\end{array}$ & $\begin{array}{l}\text { Proof } \\
\text { Withholding } \\
\text { Date }\end{array}$ \\
\hline June & $\begin{array}{l}\text { Building } \\
\text { Rental }\end{array}$ & 150.000 .000 & $10 \%$ & 15.000 .000 & 23 June 2020 \\
\hline
\end{tabular}

Table 5. Calculation of Profit After Fiscal Correction of ABC Corporation of 2020

(in Rupiah)

\begin{tabular}{lr}
\hline Profit before tax & \\
Positive Fiscal Correction & $34.525 .210,00$ \\
- Income Tax of Article 21 expense & $15.000 .000,00$ \\
- Income Tax of Article 4 paragraph 2 expense & \\
- Miscellaneous expense & $47.685 .980,00$ \\
Total Positive Fiscal Corrections & $\mathbf{9 7 . 2 1 1 . 1 9 0 , 0 0}$ \\
Negative Fiscal Correction & \\
- Bank Interest Income & $1.152 .836,00$ \\
Number of Negative Fiscal Corrections & $\mathbf{1 . 1 5 2 . 8 3 6 , 0 0}$ \\
Profit After Fiscal Correction & \\
\hline
\end{tabular}

1.213.824.033,00

Based on the 2020 Profit and Loss Statement, ABC's gross income is Rp. 24,182,809,114.00. Following the rate of Article 31E paragraph (1), Taxable Income will receive a tariff reduction of 50\% from the normal rate. Because the company's gross income is in the range of Rp. 4,8 billion up to Rp. 50 billion, taxable income will be divided into two: taxable income which entitle tax facilty and taxable income which doesnot entitle tax facilty. Taxable income which entitle tax facilty will receive a rate reduction of $50 \%$ from the normal rate of $22 \%$. Whereas for Taxable Income which doesnot entitle tax facilty, it will be subject to the normal rate of $22 \%$.

The following is the calculation of the income tax payable at ABC Corporation in 2020:

Net Fiscal Income

Rp. $1.309 .882 .387,00$

Fiscal loss compensation

Rp. $\quad 0,00$

Taxable income

Rounddown of Taxable Income

Rp. $1.309 .882 .387,00$

Rp $\quad 1.309 .882 .000,00$

The amount of taxable income resulted from part of gross income which entitle tax facilty :

$\frac{\operatorname{Rp~4,800,000,000}}{\operatorname{Rp} 24.182 .809 .114} \times \operatorname{Rp} 1.309 .882 .000,00=\operatorname{Rp} 259.995 .998,00$

The amount of taxable income resulted from part of gross income which does not entitled tax facilty:

Rp 1.309.882.387,00 - Rp 259.995.998 = Rp 1.049.886.002,00

Income Tax Payable:

- $\quad 11 \%$ x Rp 259.995.998

$=\operatorname{Rp} 28.599 .560$
$=\underline{\operatorname{Rp} 230.974 .920}$
$=\operatorname{Rp} 259.574 .480$

- $\quad 22 \% \times \operatorname{Rp} 1.049 .886 .002$

In 2020, ABC Corporation only has a domestic tax credit, namely Income Tax Article 22 of Rp. 97,353,000.00 and no foreign tax credit. Also, during 2020, the company has already paid Article 25 Income Tax of Rp. $126,972,564.00$ so that the calculation of Income Tax Payable at ABC Corporation of 2020 is as follows:

Corporate Income Tax 2020

Tax Credit

- Income Tax Article 22

- Income Tax Article 25

Income Tax 29 (Underpayment)
Rp. $259.574 .480,00$

Rp. $\quad 97.353 .000,00$

Rp. $\quad 126.972 .564,00$

Rp. $\quad 35.248 .916,00$

Some of the tables above are sourced from the tax data of ABC Corporation in 2020, which has been reprocessed for payment and reporting Income Tax 21, Income Tax 22, Income Tax 25, Income Tax 4 Paragraph 2, and Company Fiscal Correction. For 2020, there is Income Tax 29 (Underpayment) of Rp. 35,248,916.00 and had been paid on February 18, 2021. ABC Corporation reports its annual corporate income tax return on February 


\section{2,2021}

\section{Discussion.}

Based on the analysis that has been done, ABC Corporation has performed calculations, payment, and reports following applicable taxation regulations. The types of transactions, tax imposition base amount, and the rates are under Law Number 36 the Year 2008. So that ABC Corporation can be categorized as a Corporate Taxpayer who complies with the current tax regulations.

\section{CLOSING}

This study has limitations in calculating fiscal corrections at ABC Corporation during 2020 because researchers did not obtain records of $\mathrm{ABC}$ Corporation in detail. The results of the analysis are only obtained from the results of interviews and financial reports that directly divide the income and expenses included in the tax object and not the tax object. For further researchers, it is suggested to be able to obtain a detailed recording of company income and expenses in order to be able to perform fiscal correction calculations on a more accurate classification basis.

\section{REFERENCES}

Ayu, S., Endah, D., Ariee, A., \& Indarto, L., (2014). Improving Technology Acceptance Model (Tam) For The New Fixed Assets Indonesian Tax Accounting Systems. South East Asia Journal of Contemporary Business, Economics and Law, 5(1).

Ayza, B. (2017). Hukum Pajak Indonesia. Jakarta: Kencana Prenada.

Bala, G. M. M., Saerang, D. P. E., \& Elim, I. (2018). Analisis Pajak Pertambahan Nilai Dan Pajak Penghasilan Pasal 22 Pada Pt. Makmur Auto Mandiri. Going Concern: Jurnal Riset Akuntansi, 14(1), 404-411. https://doi.org/10.32400/gc.13.04.21173.2018.

Corneles, V. M., Ilat, V., \& Tirayoh, V. Z. (n.d.). Analisis Perhitungan Dan Pelaporan Pajak Atas Penebusan Lpg $3 \mathrm{~kg}$ Dari Pertamina Pada PT. Berkat Jabes.

Erythrina, Orie rahma; Punrawati, H. W. (2020). Analisis Kewajiban Perpajakan PPH 21, PPH 23 DAN PPH 4.pdf. Jurnal Multiparadigma Akuntansi Tarumanagara, 2(36), 1258-1265.

Krisanti, W., \& Dewi, D. (2020). Pajak Penghasilan Badan pada PT Redsun Lestari Tahun 2018 Jurnal Multiparadigma Akuntansi Tarumanagara. Jurnal Multiparadigma Akuntansi Tarumanagara, 2(April), 930_ 935.

Lewa, M., Kalangi, L., \& Pontoh, W. (2018). Analisis Perubahan Tarif Penghasilan Tidak Kena Pajak (PTKP) Tahun 2015 dan Tahun 2016 Terhadap Penerimaan Pajak Penghasilan (PPH) Pasal 21 di Kantor Pelayanan Pajak Pratama Bitung. GOING CONCERN: JURNAL RISET AKUNTANSI, 13(03).

Morasa, J., \& Tindagi, R. (2014). Analisis Perhitungan Pajak Penghasilan Badan Pada Pt. Golden Mitra Inti Perkasa. Jurnal Riset Ekonomi, Manajemen, Bisnis Dan Akuntansi, 2(2), 1067-1076. https://doi.org/10.35794/emba.v2i2.4487

Nur, A. A. (2019). Pengaruh Kesadaran Wajib Pajak dan Kualitas Pelayanan Perpajakan Terhadap Kepatuhan Wajib Pajak dalam Membayar Pajak Bumi dan Bangunan (PBB) di Kecamatan Stabat Kabupaten Langkat (Doctoral dissertation, Universitas Medan Area).

Priantara, D. (2013). Perpajakan Indonesia (Edisi 2 Re). Mitra Wacana Media.

Resmi, S. (2014). Perpajakan Teori dan Kasus. Salemba Empat.

RW, N. S., Bagianto, A., \& Yuniati, Y. (2018). Pengaruh Pemeriksaan Pajak terhadap Kepatuhan Wajib Pajak dan Dampaknya terhadap Efektivitas Penerimaan Pajak Penghasilan Badan. Jurnal Ilmiah MEA (Manajemen, Ekonomi, \& Akuntansi), 2(2), 115-143.

Ryan, Tinangon, J. J., \& Inggriani, E. (2014). Analisis Terhadap Koreksi Fiskal Pajak Penghasilan Pada Pt. Bitung Mina Utama Di Kota Bitung. Jurnal Riset Ekonomi, Manajemen, Bisnis Dan Akuntansi, 2(3), 1101-1111.

Sari, E, (2012). Analisis Koreksi Fiskal Dalam Rangka Perhitungan Pph Badan Pada PT. Asuransi Bumiputera Cabang Sekip Palembang. Jurnal MDP. STIE MDP, Palembang. ISSN 2303-1174

Sejanto, T. W., Elim, I., \& Tirayoh, V. Z. (2018). Analisis Perhitungan, Pencatatan Dan Pelaporan Pajak Penghasilan Pasal 25 Pada Cv. Venus Kumersot Raya. Going Concern : Jurnal Riset Akuntansi, 13(02), 464475. https://doi.org/10.32400/gc.13.02.19644.2018

Silalahi, E. M., Nugroho, L., \& Anasta, L. (2018). Analisa Mekanisme Penghitungan, Pemotongan, Penyetoran Dan Pelaporan Pajak Penghasilan Pasal 21 Pada Pt. Bina Swadaya Konsultan Tahun 2016. TEKUN: Jurnal Telaah Akuntansi Dan Bisnis, 9(1). https://doi.org/10.22441/tekun.v8i1.2600

Sondakh, S. G. (2016). Analisis Koreksi Fiskal Atas Laporan Keuangan Komersial Pada PT. Bank Perkreditan Rakyat Cipta Cemerlang Indonesia. Jurnal EMBA: Jurnal Riset Ekonomi, Manajemen, Bisnis dan Akuntansi, 3(4).

Sundah, P. L. F., Sondakh, J. J., Budiarso, N., Perhitungan, A., Pelaporan, D. A. N., Pasal, P. P. H., Pph, D. A. N., Pada, P., Sundah, P. L. F., Sondakh, J. J., \& Bisnis, F. (2020). PT MANADO MITRA MANDIRI 
CALCULATION ANALYSIS AND REPORTING OF PPH ARTICLE 25 AND PPH ARTICLE 29 IN PT MANADO MITRA MANDIRI Oleh : Jurnal EMBA Vol . 8 No . 4 Oktober 2020 , Hal . 771-780. Jurnal EMBA, 8(4), 771-780.

Supryanto, E. (2014). Akuntansi Perpajakan (Edisi Pert). Graha Ilmu.

Walandouw, P. (2013). Analisis Perhitungan Dan Pelaporan Pph Pasal 23 Dan Pph Pasal 25. Jurnal Riset Ekonomi, Manajemen, Bisnis Dan Akuntansi, 1(3), 987-997. https://doi.org/10.35794/emba.v1i3.1908

Waluyo. (2011). Perpajakan Indonesia. Salemba Empat. 